\title{
A Evolução do Direito da Responsabilidade Médica e Hospitalar na França
}

THE STRONG TENDENCIES FOR THE HOSPITAL AND MEDICAL RIGHT OF THE RESPONSIBILITY IN FRANCE

Eric Mondielli *

\section{RESUMO}

O objetivo é analisar as grandes tendências do direito da responsabilidade nos últimos anos na França, considerando a existência de dois contenciosos, o administrativo e o judiciário e as implicações do direito e da jurisprudência comunitários. Examinaram-se as questões de direito da responsabilidade médica e hospitalar, verificando-se que a atuação do ConseIho de Estado e da Corte de Cassação fez com que a noção de obrigação de informação fosse bem determinada e o campo da obrigação de segurança de resultado fosse ampliado. Implantaram-se regimes cada vez mais favoráveis ao paciente, suprimindo-se dos julgamentos a apuração do erro. Os esforços do legislador e do juiz dirigem-se todos no sentido da melhoria da reparação dos danos causados, a responsabilidade por culpa sendo o princípio e a responsabilidade sem culpa a exceção.

Assim, partindo-se da constatação que as sociedades ocidentais rejeitam a idéia do "acaso" terapêutico, sendo cada vez mais invadidas pela ilusão do risco zero, mas não se perdendo de vista que a atividade médica não é uma ciência exata, e que as tecnologias ao mesmo tempo em que trazem novas possibilidades para a obtenção de melhor estado de saúde, podem comportar riscos quando empregadas, examinou-se detalhadamente a lei sobre "os direitos dos pacientes e qualidade do sistema de saúde". Concluiu-se que o legislador essencialmente respeitou o desenvolvimento jurisprudencial sem fundamentalmente questioná-lo. A lei de 4 de março de 2002 garante a estabilidade do contencioso médico unificado em torno de

(*) Professor Associado da Faculdade de Direito de Nantes, França; Membro do Centro de Estudos e Pesquisas em Direito Europeu da Saúde de Nantes (CERDES). 
uma regra de direito comum à ordem administrativa e à ordem judiciária, mas não anula a complexidade ligada à manutenção de uma dupla competência jurisdicional.

\section{Palavras-chave}

Responsabilidade médica; Responsabilidade hospitalar; Direito dos pacientes; Democracia sanitária; Consentimento informado; Qualidade dos sistemas de saúde; Direito sanitário.

\section{ABSTRACT}

The objective of this article is to put in prospect the strong tendencies for the right of the responsibility, in France, last years, taking into account the existence of two jurisdictions, administrative and juditial, and by integrating the contribution of the Community legislation and more particularly of Community jurisprudence.

The hospital and medical right of responsibility is examined to check that the Conseil d'Etat and the Cour de Cassation gradually specified the concept of obligation of information and that the field of the obligation of safety of result is widened. It was noted that the mode of responsibility in the hospital field is characterized by the development of modes increasingly favorable to the patient and that more and more one tends to want to banish courts of the search for fault. The efforts of the legislator and the judge go overall in the direction of the improvement of the repair of the undergone damage, the responsibility for fault remaining the principle and the responsibility without fault the exception.

Thus, by recalling that the Western societies reject the idea of the "therapeutic" risk and are increasingly invaded by the illusion of the zero risk, but without loosing sight of the fact that the medical activity is not an exact science, and that increasingly pointed technologies, while constituting new contributions for a better health, can involve risks at the time of their use, one examined the law on "the rights of the patients and the quality of the system of health".

It was concluded that the legislator essentially took note of the jurisprudential developments without question then. The law of March 4, 2002 ensures the stability of the medical jurisdiction unified around a legal provision common to the administrative and the legal order, but the improvements do not evacuate the complexity related to the maintenance of a double jurisdictional competence.

\section{Key-words}

Medical responsability; Hospital responsability; Patients'rights; Health democracy; Informed consent; Health Systems'Quality; Health Law. 
A título de início de abordagem do assunto, lembramos a etimologia do termo "responsabilidade". Em latim re-spondere não deve ser traduzido por "responder", mas por "ser responsável por um compromisso" ("spondere": "prometer" ou "ser fiador"). Este lembrete etimológico ganha uma dimensão particular quando se trata da evolução do direito da responsabilidade médica e hospitalar e do direito do paciente à reparação.

Não se trata aqui de fazer uma apresentação exaustiva do estado da responsabilidade na França. $O$ objetivo, bem mais modesto, será tentar pôr em evidência e em perspectiva as grandes tendências do direito da responsabilidade nestes últimos anos. Esse exercício se revela particularmente delicado e árduo considerando-se a grande complexidade do direito na matéria: a existência de dois contenciosos, o administrativo e o judiciário que, às vezes, sobre as mesmas questões trazem respostas diferentes e, principalmente, cujos raciocínios são sustentados por diferentes lógicas (a lógica do contrato para o exercício da medicina liberal e a lógica estatutária para o exercício hospitalar). É preciso agregar também no quadro desse tipo de reflexão a abordagem do direito comunitário e principalmente da jurisprudência comunitária.

$\mathrm{Na}$ França, há vários anos, o direito da responsabilidade hospitalar e médica encontra-se em plena mudança (podemos, sem dúvida, falar de uma renovação da responsabilidade médica e hospitalar). É preciso, entretanto, dizer que as grandes crises sanitárias que atingiram nosso país no decorrer dos últimos vinte anos, tais como as questões do sangue contaminado, da doença da "vaca louca", do hormônio de crescimento, do amianto, mostraram as limitações do nosso sistema de responsabilidade ao mesmo tempo em que despertaram na sociedade francesa uma angústia e uma perda de confiança profunda. Nesse contexto de crise do direito da responsabilidade e, mais globalmente, de crise social, o Conselho de Estado francês publicou em 1998 um importante relatório intitulado "Reflexão sobre o Direito à Saúde", onde faz, principalmente, um resumo da notável evolução do direito e da responsabilidade ${ }^{(1)}$.

A análise dos mecanismos de responsabilidade é, evidentemente, um dos critérios que permitem apreciar, do ponto de vista qualitativo, a eficácia do sistema judiciário, no sentido genérico do termo. Assim, interessa examinar especialmente as questões de direito da responsabilidade médica e hospitalar: o direito à averiguação da responsabilidade, quando ela existe, e o direito à reparação do indivíduo vítima de um dano por causa do tratamento que Ihe foi dispensado, consistindo nos direitos fundamentais do paciente.

O Conselho de Estado, suprema instância administrativa, e a Corte de Cassação, suprema instância jurídica, construíram e definiram progressi-

(1) Conseil d'Etat, Rapport public 1998, réflexion sur le droit de la santé, études et document n. 49, La Documentation française, pp. 227-317, particularmente pp. 241-267. 
vamente o conteúdo da responsabilidade hospitalar e médica. Em particular, a noção de obrigação de informação(2) foi bem determinada e o campo da obrigação de segurança de resultado foi ampliado.

De forma geral, é preciso constatar que o regime de responsabilidade na área hospitalar é caracterizado pelo desenvolvimento de regimes cada vez mais favoráveis ao paciente. Veremos que cada vez mais temos tendência a suprimir dos julgamentos a apuração do erro, principalmente quando o paciente sofre danos de anormal gravidade. Os esforços do legislador e do juiz, principalmente do juiz administrativo, dirigem-se todos no sentido da melhoria da reparação dos danos causados, a responsabilidade por culpa sendo o princípio e a responsabilidade sem culpa a exceção.

Antes de irmos mais adiante nessa análise, parece necessário lembrarmos certos traços de algumas posturas adotadas atualmente pelas nossas sociedades ocidentais. Vivemos em sociedades que não mais aceitam, que rejeitam mesmo a idéia do "acaso" terapêutico, que, entretanto, faz parte da atividade curativa. Os pacientes, devido à dessacralização da atividade médica aliada ao forte crescimento, nos países europeus ${ }^{(3)} \mathrm{e}$, principalmente, na França, do reconhecimento dos direitos do paciente, com mais facilidade e com maior freqüência, questionam os médicos e mais geralmente os profissionais de saúde. Nossas sociedades são cada vez mais invadidas pela ilusão do risco zero(4). Os progressos técnicos e científicos e o sentimento de euforia que eles engendram no homem moderno, fazem-no perder de vista que a possibilidade de um dano está sempre presente.

O direito da responsabilidade, enquanto instituição, constitui, sem dúvida, um dos alicerces que devem permitir o alcance do equilíbrio indispensável entre os direitos dos pacientes e o exercício da medicina. Entretanto, tal equilíbrio, por definição delicado e difícil, talvez até impossível, é amplamente tributário das exigências sociais atuais, do peso das considerações econômicas e da capacidade dos seguros.

As exigências dos cidadãos (tratamentos de qualidade e busca de uma medicina sem falha) constituem elementos de pressão para uma

(2) V. por ex., principalmente quanto a esse ponto, o dossiê "Droits des malades information et responsabilité", Actualité et dossier en santé publique, n. 36 p. 9 et s; Sous la Dir. De P. Bon, Chron. Jurisprudence, "l'obligation d'information du médecin et responsabilité hospitalière", R.F.D.A., n. 16 (3), mai.-juin 2000, p. 636 et s; L. Dubouis, "Le droit du patient à l'information: harmonisation des jurisprudences civiles et administrative et problèmes de mise en œuvre", note sous CE, 5 janv. 2000, Assistance publique-Hôpitaux de Paris; Consorts Telle, R.D. Sanit. Soc., n. 36 (2), avr.juin 2000 , p. 357 et $s$.

(3) Desse ponto de vista, podemos pensar particularmente na Holanda; V. por ex. B. Wijnberg (chefe da divisão "ética médica" do ministério da saúde holandês), "La situation juridique des patients: approche de droit comparé", in les Petites affiches, 21 mai 1997, n. 61, pp. 18-19.

(4) Sobre essa tendência e as criticas a ela feitas V. C. HUGLO, "Le concept de risque zéro, fausse solution, mais vrai problème", in Revue de Philosophie Politique, 2000, n. 11, p. 57 et s. 
necessária adaptação dos conceitos de responsabilidade. Se, porém, para os pacientes o direito de reparação de um dano constitui um dos seus direitos fundamentais, não devemos perder de vista que a atividade médica não é uma ciência exata, e que as tecnologias, cada vez mais avançadas, ao mesmo tempo em que trazem novas possibilidades para a obtenção de melhor estado de saúde, podem comportar riscos quando empregadas.

$\mathrm{Na}$ França, no dia 4 de março de 2002, foi publicada a lei sobre "os direitos dos pacientes e qualidade do sistema de saúde"(5). Esse texto modifica sensivelmente seções importantes do Código de Saúde Pública. Mas, globalmente, parece que o legislador essencialmente respeitou o desenvolvimento jurisprudencial sem fundamentalmente questioná-lo. Assim, numa primeira parte, parece oportuno fazer um resumo da situação do direito da responsabilidade médica e hospitalar anterior a essa lei. De forma geral, esse direito ficou sempre ancorado na culpa, apesar das várias atenuações ou interpretações favoráveis aos pacientes (I). Na segunda parte, será examinada a contribuição dessa lei para os direitos dos pacientes no que diz respeito à responsabilidade e à indenização. De fato, de acordo com os termos do projeto de lei apresentado pelo governo francês, o legislador deveria, por um lado, precisar, unificar e estabilizar as regras em matéria de responsabilidade médica em caso de acidente médico e, assim, remediar o custo e a lentidão dos processos, as incertezas ligadas à evolução permanente da jurisprudência e à sua diversidade de acordo com a jurisdição competente, e por outro lado, definir um novo direito à indenização para a hipótese de "acaso" terapêutico. Essa lei, consagrando um retorno à culpa, ao mesmo tempo instituiu um meio extrajudicial de indenização da vítima. (II).

\section{O DIREITO DA RESPONSABILIDADE MÉDICA E HOSPITALAR, UM DIREITO SEMPRE ATRELADO À CULPA}

As regras da responsabilidade médica e hospitalar foram essencialmente elaboradas sem qualquer suporte legislativo. Antes de estudar as grandes tendências em matéria de direito da responsabilidade médica e hospitalar, parece importante fazer alguns lembretes de ordem histórica e jurídica (A), para melhor avaliar a aproximação "incompleta" da jurisprudência judiciária e administrativa aplicada antes da adoção da lei sobre os direitos dos pacientes e a qualidade do sistema de saúde, de 4 de março de 2002, para conceder aos pacientes o direito fundamental à reparação das conseqüências de uma terapia danosa (B).

(5) Lei n. 2002-303, de 4 de março de 2002, relativa aos direitos dos pacientes e à qualidade do sistema de saúde, J.O. n. 54 du 5 mars 2002, p. 4.118. 


\section{A - Lembretes históricos sobre a evolução do direito da responsabilidade médica e hospitalar}

No plano estritamente histórico e a fim de "definir um cenário", podemos lembrar que se o direito da responsabilidade médica apareceu, na França, no início do século XIX, de fato, foi necessário esperar o fim do século e toda a primeira parte do século $X X$ até os anos 50 , para que a questão da responsabilidade médica chamasse realmente a atenção da doutrina jurídica francesa. Todavia, o desenvolvimento dos conhecimentos e das técnicas na área sanitária irá apressar os fatos e contribuir "mecanicamente" para incentivar a pesquisa e a reflexão jurídica e, também, para o que chamaríamos hoje a reflexão sobre a "bioética" e sobre o "biodireito"(no sentido anglo-saxônico).

Sem mais delongas quanto a essa dimensão histórica, nos limitaremos a mencionar a incontornável decisão "Mercier" de $1936^{(6)}$, na qual o juiz judiciário francês afirmava que o médico se encontrava numa situação contratual em relação ao seu paciente (o paciente depositando sua confiança no quadro jurídico de natureza contratual( $\left.{ }^{(7)}\right)$. Contrato civil de natureza específica, esse contrato sinalagmático compreende diversas obrigações para o médico a obrigação de informar o paciente quanto ao seu estado de saúde, quanto ao tratamento proposto e seus riscos; obrigação de aconselhá-lo, de obter o seu consentimento e de tratá-lo; e para o paciente a obrigação de, na medida do possível, informar o médico dos seus antecedentes, de seu estado e de pagar os honorários médicos. Como tivemos a oportunidade de sublinhar ${ }^{(8)}$, essa abordagem não poderia, evidentemente, ser transposta para o direito hospitalar, na medida em que o estabelecimento público hospitalar não está ruma relação contratual com o paciente. Juridicamente, o paciente é "um usuário do serviço público hospitalar"(9), portanto, ele é submetido a um regime de direito público, sendo o contencioso submetido ao juiz administrativo. Em outras palavras, o paciente "usuário" não está numa situação contratual, mas estatutária ${ }^{(10)}$. Por muito tempo, porém, "a

(6) Civ., 20 mai 1936, Gaz. Pal., 1936.2, p. 41; S., 1937.1.321, note A. Breton; D. 1936.1.88, concl. Matter, rap. Josserand, note E.P.

(7) V. G. Mémeteau, traité de la responsabilité médicale. Les études hospitalières, Bordeaux, 1996.

(8) V. Cyril Clément, la responsabilité du fait de la mission de soins des établissements $s$ publics privées de santé, thèse, droit 1997, Paris VIII, V. Jean-Marie Clément, Le juge français et les droits des patients: l'exemple du sang contaminé, in "La situation juridique des patients", Centre d'études et de recherches en droit européen de la santé -CERDES- Bordeaux, 24-25 janvier 1997, Les Petites Affiches, du 21 mai 1997, n. 61, p. 15.

(9) CE, Sect., 21 fév. 1936, SA Les Armateurs Français, Rec. Leb., p.226, v. J-M de Forges et F. Seuvic, L'Hospitalisé, éditions Berger-Levrault, coll. "L'administration nouvelle".

(10) V. por ex. CE. 4 oct. 1968, Mlle Doukakis, Rec. Leb., p. 903.

O consumidor está numa situação estatutária na medida em que é submetido a um regime jurídico preestabelecido (sobre esse ponto v. J. Moreau et D.Truchet, Droit de la santé publique, coll. Mementos Dalloz, 5éme édition, 2000, p. 270).

O paciente "consumidor":

- dispõe de direitos e de possibilidades de recursos; 
idéia de questionar a responsabilidade do estado decorria mais da incongruência do que da lógica de um pedido de reparação"(11). Se o princípio da responsabilidade do Estado foi admitido com a decisão Blanco de 1873, consagrando esse tipo de responsabilidade independentemente de qualquer texto(12), o princípio da irresponsabilidade foi mantido por muito tempo, em importantes áreas de atividade administrativa ${ }^{(13)}$. Quanto à possível responsabilidade da medicina hospitalar, ela só foi admitida bem mais tarde, em 1935, com as decisões Vion e Philiponeau(14). Só a partir dos anos 70 se desenha progressivamente uma tendência de fundo visando a reconhecer verdadeiramente aos pacientes um direito à reparação dos danos em conseqüência de um tratamento. Esse movimento pode se desenvolver graças à aproximação, principalmente na última década, da jurisprudência administrativa e judiciária. O Conselho de Estado se aproximou das jurisdições da ordem judiciária abandonando em 1992 a noção de falta grave para que um hospital possa ser condenado com base num doente reconhecido(15). Após ter admitido a noção de responsabilidade por falta leve, o Conselho de Estado vence uma nova etapa condenando a atividade médica hospitalar por risco ou por perda de oportunidade ${ }^{(16)}$. Assim, globalmente, a jurisprudência administrativa se mostra muito liberal em relação às vítimas.

B - A aproximação "incompleta" da jurisprudência judiciária e administrativa para reconhecer aos pacientes o direito fundamental à reparação das conseqüências de um tratamento danoso

O traço marcante da evolução mais recente reside na preocupação comum ao juiz civil e administrativo no sentido de que todo paciente que sofreu danos em conseqüência de um tratamento seja indenizado. Todavia, os caminhos usados pelo juiz administrativo e civil são às vezes muito diversos e fundados em lógicas jurídicas diferentes, dos quais resultam certas distorções de apreciação que não podem ser evitadas.

Com a dessacralização da medicina durante o século $X X$ e os progressos científicos e técnicos sem precedentes na história, cada vez me-

\footnotetext{
- suporta obrigações que resultam dos princípios gerais aplicáveis a todo consumidor de serviço público e de regulamentos aplicáveis ao estabelecimento no qual ele foi acolhido, que regem a organização e o funcionamento do serviço;

- não pode estabelecer por meio de acordo com o estabelecimento as regras aplicáveis ao seu relacionamento recíproco.

(11) Jean-Marie Clément, "Le juge français et les droits des patients: l'exemple du sang contaminé", in "La situation juridique des patients", Ateliers de droit européen de la santé (CERDES), Les Petites affiches, 21 mai 1997, n. 61, pp. 15-17.

(12) Trib. Confl., 8 février 1873, Rec. Leb., p. 61.

(13) Sobre esses pontos v. J-A Bas, "L'évolution de la responsabilité hospitalière", in Les Petites affiches, 6 nov. 2001, n. 221, pp. 5-10.

(14) Arrêt Philliponeau Rec. p. 1020, arrêt Dame Vion 8 nov. 1935, Rec. p. 1.019.

(15) CE. Ass. 10 avr. 1992, Epoux V., 1992, Rec. Leb. p.173.

(16) CE Ass. 9 avril 1993, Bianchi, Rec. Leb., p. 127.
} 
nos se hesita em questionar a responsabilidade do médico pelos erros cometidos no uso ou não-uso de novas ferramentas científicas no âmbito do exercício de sua função. Além dessa dimensão, outras razões puderam ser levantadas para explicar a evolução do direito da responsabilidade nas nossas sociedades ocidentais e particularmente na França. Conforme o que foi claramente salientado pelo Conselho de Estado francês, no seu relatório de 1998 "Reflexão sobre o direito à saúde", o estado de direito, protetor dos "direitos-liberdades", pilares fundadores da República, integra de forma progressivamente mais marcada os direitos de crédito "que os indivíduos pleiteiam como a sua parte no contrato social". Ao mesmo tempo, o enfraquecimento do Estado-providência engendra uma individualização das relações sociais. O cidadão, agente da solidariedade, teria tendência a ser substituído por um indivíduo animado com uma filosofia de indenização e que se concebe como vítima do outro(17). Entraríamos, assim, com esse processo de "vitimização", numa "sociedade reparadora generalizada" segundo uma fórmula de Pierre Rosanvallon ${ }^{(18)}$ (aliás, retomada pelo Conselho do Estado no seu relatório), na qual se procura "em todas os azares e injustiças da vida uma fonte de financiamento e de redistribuição"(19). Desta forma, a Europa seria progressivamente atingida por esta postura ideológica bem conhecida nos Estados Unidos. O paciente faz questão absoluta de identificar um responsável pelo dano causado e de pedir uma indenização. Entramos na era da busca de um responsável a qualquer preço, com uma série de conseqüências e riscos inerentes a essa investigação (espectro de uma medicina defensiva, insegurança jurídica para os profissionais e estabelecimentos de saúde em razão de permanentes mudanças na jurisprudência, aumento considerável dos prêmios de seguro etc.), para as nossas sociedades.

A evolução do direito da responsabilidade é dominada por três tendências: primeiramente, se pode constatar um crescimento da obrigação de resultados; em segundo lugar, em matéria de responsabilidade hospitalar pública, se assiste à passagem da culpa grave para a responsabilidade médica; e, enfim, se nota a irrupção notável da responsabilidade sem culpa.

\section{O crescimento da obrigação de resultado}

Fundamentalmente a Cour de Cassation francesa permanece ligada à doutrina oriunda da decisão Mercier de 1936, segundo a qual "forma-se entre o médico e seu cliente um verdadeiro contrato abrangendo, para o profissional, o compromisso, se não de curar o paciente..., de ao menos propiciar-Ihe tratamentos... conscienciosos, atentos $e$, com a reserva dos casos excepcionais, conforme os resultados das pesquisas científicas; que

(17) EDCE, ob. cit., p. 241.

(18) Pierre Rosanvallon, "La nouvelle question sociale", Le Seuil, 1995, p. 65.

(19) EDCE, ob. cit., p. 241. 
a violação, mesmo involuntária, dessa obrigação contratual, é sancionada por uma responsabilidade da mesma natureza, também contratual". Em outras palavras, a obrigação do médico é uma obrigação de meio, o que se adapta ao caráter incerto da prática médica, além do que, em princípio, a responsabilidade do profissional de saúde só pode ser promovida se ele cometer uma falta quanto a essa obrigação. Ocorre que essa obrigação de meio sofreu progressivamente diversas atenuações, o que permitiu a alguns observadores dizer que a obrigação de meio encolhia inexoravelmente como uma "peau de chagrin"(20). Com efeito, em alguns casos, a Cour de Cassation exige do médico uma verdadeira "obrigação de garantia do resultado", que tem por conseqüência tornar o médico responsável, seja ou não estabelecida a culpa, salvo se trouxer a prova de uma outra causa. Duas áreas parecem bem exemplificar as hipóteses em que os médicos suportam tal obrigação: a dos dispositivos médicos e a das infecções nosocomiais.

- A obrigação de garantia do resultado diz respeito aos produtos, materiais, documentos e, de uma forma geral, aos dispositivos médicos, usados pelo médico para os tratamentos dispensados ao paciente.

De fato, a jurisprudência francesa tem progredido na questão em direção à obrigação de garantia do resultado(21). Por exemplo, muito cedo a Cour de Cassation responsabilizou os cirurgiões dentistas por uma obrigação de resultado no que diz respeito ao fornecimento de próteses dentárias, submetendo-os a uma obrigação de meio quando da colocação dessa prótese, por se tratar de um ato médico(22).

Com as decisões "HIV", de 12 de abril de 1995, que dizem respeito à face cível da questão chamada de "escândalo do sangue contaminado", a evolução parece mais clara ${ }^{(23)}$. Nesta questão, percebe-se que o juiz judiciário alterna entre a obrigação de meio e a obrigação de resultado(24). A Corte aceitou a responsabilidade por culpa da clínica após a contaminação do paciente por via de transfusão, determinando que pesa sobre a clínica "a obrigação de prudência e de zelo no fornecimento de produtos sangüíneos entregues por um Centro de Transfusão Sangüínea" (por outras palavras, trata-se, neste caso, de uma obrigação de meio). Por outro lado, a Cour de Cassation, com referência aos Centros de Transfusão Sanguínea - CTS, aceita também a responsabilidade por culpa, mas ela determina para os

(20) Cf. Cyril Clément, "1990-2002: une période jurisprudentielle faste pour les droits des patients", Revue Générale de Droit Médical, n. 7, 2002, pp. 31-46.

(21) Arrêt Bernard du 22 novembre 1994, Bull. civ., I, n. 34.

(22) Arrêt Bismuth du 29 octobre 1985, Bull. civ. I, n. 273.

(23) Decisões conhecidas como Arrêts du VIH du 12 avril 1995, Bull. civ. I, n.179 et 189, Rapp. Ann. C. Cass. p. 309.

(24) V. J-M. Clément, "Le juge français et les droits du patients: l'exemple du sang contaminé", in Ateliers de droit européen de la santé "La situation juridique des patients", Centre d'étude et de recherche en droit européen de la santé (CERDES), n. spécial, n.61, Les Petites affiches, 21 mai 1997, pp. 15-17. 
CTS uma obrigação de resultado: "os centros de transfusão de sangue são obrigados a fornecer aos recebedores produtos isentos de vícios e eles não podem ser isentos dessa obrigação de segurança a não ser pela prova de uma causa estranha que não seja atribuída a eles". Trata-se aqui, por outras palavras, de uma obrigação de resultado. Pode-se, assim, compreender a estranheza de alguns comentaristas quanto às divergências entre essa jurisprudência e aquela relativa à clínica, lamentando a falta de alinhamento delas ${ }^{(25)}$. A título de precisão e de comparação, pode-se esclarecer que, quanto à face administrativa dessa mesma questão do sangue contaminado, o Conselho de Estado aceitou o princípio da reparação das conseqüências danosas da má qualidade dos produtos sanguíneos fornecidos, mesmo na ausência de qualquer culpa ${ }^{(26)}$. Entretanto, o juízo administrativo fez pesar a obrigação de garantia sobre os CTS que forneceram sangue contaminado, e os estabelecimentos de saúde respondem apenas por erros cometidos no uso dos produtos sangüíneos. Com outras palavras, o problema da responsabilidade pelos prejuízos sofridos depois de uma transfusão esteve sempre sem resposta.

Esta tendência no que se refere à garantia de resultado é confirmada em seguida com uma decisão da Cour de Cassation em 9 de novembro de $1999^{(27)}$. Essa decisão aparece como uma generalização de obrigação de resultado a cargo do médico e da clínica por tudo que diz respeito à segurança do paciente. A jurisdição suprema da ordem judiciária considerou de fato que "o contrato feito entre o paciente e seu médico obriga o último, sem prejuízo de seu recurso de garantia, a uma obrigação de garantia de resultado no que se refere aos materiais que ele usa para o tratamento médico, sendo necessário ainda que o paciente prove que eles estão na origem dos danos". Para os estabelecimentos de saúde privada, a Cour de Cassation considera que "o contrato de hospitalização e de tratamentos, ligando o paciente a um estabelecimento de saúde privada, coloca sob a responsabilidade deste, sem prejuízo da garantia de seu recurso, uma obrigação de garantia de resultado no que diz respeito aos produtos, tais como medicamentos, que ele fornece"(28).

Esses desenvolvimentos jurisprudenciais não são em si surpreendentes se comparados com a lógica da lei de 29 de maio de 1998, relativa à responsabilidade pelo fato de produtos defeituosos. Esse texto instaurou um regime de responsabilidade objetiva do produtor e dos fornecedores profissionais dos produtos de saúde, com a condição, entretanto, de que a vítima traga a prova de que o produto na origem do dano apresenta um

(25) CF. J-M.Clément, ob.cit., p. 18; P. Jourdain, nota J.C.P. 1995, II. 22467, doc. 9.

(26) CE Ass. 26 mai 1995, R.F.D.A., p. 748, concl. Daël.

(27) Cass. Civ. 1ere 9 nov. 1999, D. 2000 p. 117 note P. Jourdain, J.C.P. 2000. II. 10251, note Brun; Revue générale de droit médical, 2000, n.3, p. 89, rapport P. Sargos, note C. Caillé.

(28) Civ. 1re, 7 novembre 2000, J.C.P., 2001, I, 340. 
defeito, definido como a ausência da segurança que o consumidor pode legitimamente esperar (conseqüentemente, indicando o efeito indesejável na bula do medicamento, é possível afastar a responsabilidade do fabricante, uma vez que o paciente não pode legitimamente esperar uma segurança total em relação a esse risco). Aqui se notará, igualmente, que o juiz comunitário considera que a responsabilidade do fato do produto se aplica em matéria médica quando o produto defeituoso "for usado numa prestação de serviços concreta, de natureza médica, consistindo em preparar um órgão humano a ser transplantado e que o dano causado ao órgão for conseqüência desse preparo"(29). O impacto da jurisprudência comunitária só pode instigar o juiz administrativo a aproximar-se do juiz civil.

- A questão das infecções hospitalares e a afirmação de uma obrigação de garantia de resultado(30).

É bem sabido que a luta contra as infecções contraídas num estabelecimento de saúde constitui um desafio permanente para o profissional de saúde. Segundo estudos $10 \%$ das pessoas hospitalizadas seriam atingidas por uma infecção hospitalar quando de sua passagem por um estabelecimento de saúde e essas infecções ocasionariam diretamente quase 10.000 óbitos por ano(31). A análise da evolução do contencioso destes últimos anos evidencia que a jurisprudência, tanto do juízo civil quanto do administrativo, é bastante favorável aos pacientes. A fim de favorecer a indenização do paciente-vítima de infecção hospitalar, o princípio de presumir a culpa foi mantido por ambas as ordens de jurisdição( ${ }^{(32)}$. O Conselho de Estado com a decisão Cohen de 9 de dezembro de $1988^{(33)}$, pela primeira vez aceitou o regime de presunção de culpa em matéria de infecção hospitalar. Com a finalidade de favorecer a indenização, a jurisdição administra-

(29) C.J.C.E., 10 mai 2001, D. 2001, p. 3065, note P. Kayser; v. sobre a reflexão comunitária em matéria de produtos defeituosos P. Flavin, "Etablissements de santé et directive européenne du 25 juillet 1985 sur les produits défectueux", SHAM Contact, décembre 2001.

(30) A circular de 13 de outubro de 1988 , relativa à organização do controle e à prevenção das infecções hospitalares, a define como: toda doença provocada pelos microorganismos, contraída num estabelecimento de tratamento por qualquer paciente admitido, seja para um tratamento hospitalar, seja para tratamentos ambulatoriais, que os sintomas apareçam no dia da hospitalização ou depois, que a infecção seja detectada clinicamente ou microbiologicamente. Em 1992, a definição foi ampliada pelo Conselho Superior de Higiene da seguinte forma: são infecções ausentes quando da admissão no hospital.

(31) Segundo estudos, podemos contar 800.000 pacientes atingidos por esse tipo de infecção e são estimados na ordem de 10.000 óbitos. Entre os setores mais atingidos estão a cirurgia e a reanimação. Enfim, certos números são bastante preocupantes vez que algumas estatísticas demonstraram que um paciente tem $100 \%$ de chance de ser atingido por uma infecção hospitalar se ele passar um mês em UTI. Cf. L'Express, 8 mars 2001, "Hôpitaux, cliniques: ce que l'on vous cache", S. O'Dy et M. Batiste; v. também o artigo de R. Rayssac "Le sort des infections nosocomiales", in Actualités JuriSanté, n. 34 - déc. 2001- janv. 2002, p. 50.

(32) Antigamente, a indenização do paciente vítima de tais infecções era subordinada ao regime de responsabilidade por erro, o que o colocava numa difícil posição, uma vez que ele tinha que provar o erro, o dano e a ligação entre o erro e a reparação.

(33) CE.9 dec. 1988, Rec. Leb., p. 431. 
tiva "desmedicalizou" - fazendo nossa a fórmula usada por um comentador - a responsabilidade hospitalar, colocando-a no terreno da organização do serviço. Para o juiz "enquanto nenhuma culpa médica grave em relação à assepsia pode ser atribuída aos médicos que praticaram a intervenção, o simples fato de que uma injeção tenha podido ser ministrada revela uma falta na organização e no funcionamento do serviço".

Aqui se pode entender facilmente a importância do recurso à presunção da culpa, pois o seu efeito é inverter o ônus da prova, impondo ao defensor demonstrar que nenhuma culpa que lhe possa ser atribuída está na origem do dano. Entretanto, conforme lembrou o relatório do Conselho de Estado de 1998, se o recurso à presunção da culpa é lógico quando a culpa é impossível de ser provada, embora seja manifesta (como foi o caso, por exemplo, da contaminação por varíola de um paciente que foi hospitalizado por descuído no mesmo quarto com outro paciente suspeito de ser portador desta doença tão contagiosa $\left.{ }^{(34)}\right)$, por outro lado, esse regime de responsabilidade parece manifestamente grave em relação a um estabelecimento hospitalar que tomou todas as medidas sanitárias adequadas e que, portanto, não cometeu faltas. De fato, não podemos perder de vista que é impossivel eliminar todas as fontes ponteciais de contaminação num estabelecimento de saúde. Freqüentemente, os estabelecimentos de saúde se encontram na impossibilidade de demonstrar que não cometeram faltas. Esta situação levou o Conselho de Estado a afirmar que "existe portanto um hiatus entre a realidade técnica e o princípio em si do regime da responsabilidade por presunção de culpa"(35). Esta situação explica, sem dúvida, porque em 1999 algumas decisões consideraram que mesmo que nenhuma culpa tenha sido provada, por exemplo, num procedimento de esterilização, o estabelecimento de saúde pôde ser condenado a indenizar a vítima ${ }^{(36)}$.

A Cour de Cassation com a decisão Bonnici de 21 de maio de 1996 presumiu a culpa considerando "que uma clínica é presumida responsável por infecção contraída por um paciente durante uma intervenção realizada em sala de cirurgia, a não ser que prove o contrário"(37). Note-se, também, que em 1998 a Cour de Cassation, confirmando essa jurisprudência, assimilou a sala de partos ao bloco operatório ${ }^{(38)}$.

No que diz respeito às infecções hospitalares, o juiz judiciário irá proceder a uma mudança de jurisprudência por ocasião de três decisões em 29 de junho de $1999^{(39)}$, considerando que os estabelecimentos de saúde e

(34) V. a decisão Savelli 18 de novembro de 1960, Rec. Leb., p. 640, que é a primeira decisão do Conselho de Estado no tocante a um problema de infecção hospitalar.

(35) EDCE, 1998, p. 247.

(36) V. neste sentido CE 31 mars 1999, Assistance publique de Marseille, n. 1817019.

(37) Cf. D., 1997, som., p. 287, obs. Mazeaud.

(38) Cf. Arrêt Clinique Belledone, Bull. civ.l. n. 210, 1997.

(39) Cf. J.C.P., ed. G., 1999, II, n. 10138. 
os médicos eram obrigados à garantia de resultado. De fato, a Corte declarou que "Considerando que o contrato de hospitalização e de tratamentos, estabelecido entre o paciente e o estabelecimento de saúde, implica para este último, em matéria de infecção hospitalar, uma obrigação de segurança e de resultado, da qual ele não pode se libertar a não ser que prove a culpa de terceiro, e Considerando que o médico está vinculado, em relação ao seu paciente, a uma obrigação de segurança e de resultado, da qual ele não pode se libertar a não ser que prove a culpa de terceiro". Notese, também, que a Cour de Cassation estendeu essa obrigação às infecções hospitalares ocorridas após atendimento realizado em consultório médico ${ }^{(40)}$. A seguir, a Cour de Cassation limitou o alcance das decisões de 1999, argumentando, numa decisão de 27 de março de 2001(41), que cabia ao paciente demonstrar que a infecção que o acometeu apresenta um caráter hospitalar e, neste caso, o médico está vinculado à obrigação de garantia de resultado.

Quanto ao juízo administrativo, ele não aceita a obrigação de garantia de resultado em matéria de infecção hospitalar, mesmo que ele admita há muito tempo que em matéria de higiene pesa sobre o hospital uma "verdadeira obrigação de resultado"(42).

A evolução do contencioso judiciário destes últimos anos, na área de infecção hospitalar, demonstra perfeitamente a inadequação do direito francês da responsabilidade. Numerosos observadores clamaram fortemente para que se reflita sobre outros sistemas de reparação sem passar pelo jogo da responsabilidade, a não ser que uma falta de higiene seja caracterizada $^{(43)}$. Neste contexto, era, portanto, importante que o legislador se dedicasse a esse aspecto do problema.

\section{A responsabilidade hospitalar pública: da culpa grave à culpa médica}

Como já foi mencionado, só em 1935 rompemos com o período de irresponsabilidade do médico-hospitalar e nos vinculamos ao princípio de uma responsabilidade por culpa. Nunca será demais destacar que "a equação natural entre responsabilidade e culpa é explicada pela incidência da moral sobre um direito que só deveria sancionar o 'ilícito', a culpa daria ao direito comum da responsabilidade administrativa um valor de sanção e moralização"(44).

(40) Arrêt du 13 février 2001, V. J.C.P. 2D. G., 2001, IV, n. 1639.

(41) Cf. Dr. Et patr. 2001, n. 95, p. 106, obs. F. Chabas.

(42) V. nesse ponto S. Daël, Concl. CE 9 avril 1993, Bianchi, R.F.D.A, 1993, p.573.

(43) Cf. Cyril Clément, "1990-2002: une période jurisprudentielle faste pour les droits des patients", Revue Générale de Droit Médical, n. 7, 2002, pp. 31-46.

(44) S Clavé, "La responsabilité médicale à l'hôpital public". Évolutions et perspectives, éd. Séli Arlan, 2002, p. 73. 
O contencioso da responsabilidade hospitalar pública tradicionalmente distingue, de um lado, a atividade do serviço administrativo do hospital que reclama a culpa leve e, de outro, a atividade do serviço médico que exige a culpa grave ${ }^{(45)}$. A exigência da culpa grave era na realidade ligada ao caráter difícil da atividade, a uma execução marcada pela urgência ou pelo acaso dos seus resultados. De forma geral, os serviços públicos mais técnicos tinham sua responsabilidade promovida apenas com base na culpa grave $^{(46)}$. Progressivamente, o juiz administrativo vai aperfeiçoando sua construção jurisprudencial. Sem entrar nos detalhes, lembraremos aqui simplesmente as grandes etapas desta evolução.

A culpa leve será, no passo seguinte, suficiente para promover a responsabilidade em matéria de tratamentos. Por outro lado, no que se refere aos atos médicos, a responsabilidade está ligada à culpa grave ${ }^{(47)}$.

Em seguida, o Conselho de Estado aceitará a presunção de culpa para os atos de tratamentos correntes, como por exemplo as injeções na veia(48), depois a presunção de culpa para as perfusões, os atos de fisioterapia ${ }^{(49)}$. Depois disso, a presunção de culpa será aceita para os danos resultantes de atos médicos muitos difíceis, que são traduzidos em complicações infecciosas. Esta evolução pode ser explicada pela vontade de indenizar as vítimas ${ }^{(50)}$.

Aos anos 90 está ligada a tendência para a culpa grave. Conforme alguns estudos puderam evidenciar(51), os que foram sujeitos à ação da justiça perceberam o regime da culpa grave como uma limitação injustificada da responsabilidade. Com a finalidade de "adaptar os perfis do princípio de responsabilidade às exigências da época", o Conselho de Estado irá progressivamente abandonando a culpa grave para os atos médicos com a decisão Epoux V. de 10 de abril de 1992(52). Este abandono deve ser mais

(45) Para uma apresentação clara e curta sobre a evolução do contencioso administrativo sobre a matéria v. J-A Bas, "L'évolution de la responsabilité hospitalière", in "Les Petites affiches", 6 nov. 2001, n. 221, pp. 5-10.

(46) Cf. J. Moreau, "La responsabilité administrative professionnelle?", in "Les Petites affiches", 11juillet 2001, n. 137, pp. 25-28, p. 26.

(47) V. CE 26 juin 1959, Rouzet, p. 405. Era importante ter-se uma definição da noção dos atos médicos, na medida em que, às vezes é difícil distinguir os tratamentos dos atendimentos médicos. A decisão de 1959 dá aos atos médicos a seguinte definição: "todos os atos que para serem cumpridos apresentam dificuldades sérias e requerem conhecimentos especiais adquiridos através de estudos prolongados"; por outras palavras, estes atos só podem ser realizados por "um médico ou cirurgião" ou por "um assistente-médico sob sua responsabilidade e controle direto". Quanto aos tratamentos não médicos, trata-se de atos corriqueiros de caráter benigno.

(48) CE 23 fev. 1962, Meier, Rec.l Leb., p. 122.

(49) CE 22 nov. 1976 Derridj, Rec., p. 576; CE 19 mai 1976 C.H.R. de Potiers, Rec. p. 266.

(50) CE 9 dez. 1988 Cohen, Rec., ob. cit., p. 431.

(51) V. J-A Bas, "L'évolution de la responsabilité hospitalière", ob. cit. V. J-H Stahl, "Le déclin de la faute lourde (le cas des services d'aide médicale d'urgence)", concl. Sur CE., section, 20 juin 1997, Theux, R.F.D.A., janvier-février 1998, p. 86.

(52) CE 10 avril 1992, Expoux V., Rec. p. 171; na realidade, o caso de madame V. enquadravase bem nesta evolução de jurisprudência. Esta pessoa tinha sido vítima de uma sucessão de 
analisado como remate de uma evolução do que como uma revolução. De fato, vimos que a exigência de culpa grave foi-se tornando mais maleável e perdendo seu caráter excepcional, que levava a doutrina a falar, até o início dos anos 80 , da "inencontrável culpa grave". Os progressos médicos e as crescentes exigências dos justiciáveis levaram, se assim se pode dizer, 0 Conselho de Estado a abandonar a distinção anterior (culpa leve/atos de cuidados, culpa grave/atos médicos) que era cada vez menos compreendida tanto pelas vítimas quanto pelos médicos. Entretanto, é importante sublinhar que a obrigação dos médicos é sempre uma obrigação de meios e não de resultado. Abandonando a exigência da culpa grave, é claro que o juiz administrativo não pretende sancionar, no futuro, todos os erros médicos por mais benignos que sejam. Com efeito, todo erro não é obrigatoriamente culposo. Pensar diferentemente seria o mesmo que impor aos médicos uma verdadeira obrigação de resultado, o que não pode ser admitido tratando-se de uma ciência onde existe uma parte de incerteza e de imponderável. Com a decisão Epoux V., o Conselho de Estado colocava um final ao que parecia ser um ponto de divergência entre a jurisprudência administrativa e a jurisprudência judiciária. Desta forma, no decorrer dos anos 90 pudemos assistir à uniformização do regime de responsabilidade por culpa em matéria hospitalar em torno da exigência da culpa leve, seja para os atos médicos, cirúrgicos ou para a atenção médica de urgência. Porém, os juízes, movidos sempre pela preocupação de indenizar as pessoas vítimas de acidentes terapêuticos, irão, a partir de então, tender para a responsabilidade sem culpa baseada no risco.

\section{A irrupção da responsabilidade sem culpa}

Nos anos 90, assistiu-se a um desenvolvimento das possibilidades de recorrer à responsabilidade sem culpa para as pessoas hospitalizadas $^{(53)}$, que foram expostas a um risco de danos especiais, pelo fato de

erros, de imperícia ou de imprudência em diversas intervenções médicas, sendo que nenhuma foi enfocada em particular, para justificar falta grave, porém todas em conjunto caracterizavam um comportamento errado cuja casualidade prejudicou o requerente sem contestação. Após uma parada cardíaca de meia hora durante uma banal cesária, madame $V$. ficou alguns dias em coma, e se posteriormente recuperou-se de uma hemiplegia esquerda massiva, ela tinha, entretanto, mantido importantes seqüelas neurológicas. Os especialistas tinham destacado as cinco etapas críticas do desencadeamento infeliz que tinha levado a esse acidente, porém a manutenção de falta grave teria sem dúvida levado à exclusão de qualquer indenização da vítima.

(53) Devemos, entretanto, assinalar que antes deste período o juiz administrativo já tinha aplicado a responsabilidade sem culpa do serviço público hospitalar:

- foi, por exemplo, o caso dos danos sofridos pelos colaboradores ocasionais dos hospitais (v. CE 13 dez. 1957, Hôpital-hospice de Vernon, Rec., p. 680) ou dos danos causados a terceiros por ocasião de colocação de doente mental em ambiente familiar monitorado (v. CE 13 mai 1987, Mme Piollet et Anson, Rec. p. 172). O Conselho de Estado no seu relatório de 1998 teve, entretanto, 0 cuidado de lembrar que estas decisões não constituiram de forma alguma desvios do princípio 
terem sido submetidas a certos métodos terapêuticos ou, de forma geral, a determinados procedimentos médicos.

$\mathrm{Na}$ medida em que ignora o comportamento do autor do ato prejudicial para limitar-se a constatar de fato o dano material, a responsabilidade sem culpa permitirá, de um lado, responder aos anseios da opinião pública por uma reparação mais ampliada dos danos médicos e, por outro lado, de afirmar, usando uma expressão do Prof. Didier Truchet, a idéia de "não deterioração do fato do hospital"(54). Retomando, por minha conta, a análise de $S$. Clavé, deve-se considerar que esse argumento não pode ser válido para o conjunto das situações e das atividades do serviço público, mas em compensação ele corresponde, por excelência (particularmente quando ele é baseado na noção de risco), às atividades que, mesmo sendo perigosas, são desenvolvidas nos serviços públicos no cumprimento de sua missão. "Ora, a especificidade principal e original do contencioso hospitalar reside no fato de que os riscos que o serviço médico é levado a correr são, de forma geral, de interesse dos pacientes. Estender o regime de responsabilidade sem culpa aos usuários do serviço público seria transferir a reparação dos danos imputáveis ao acaso médico para o hospital, solução que não é legitimada por nenhum princípio jurídico, nem a eqüidade. O problema não seria então de sancionar uma ação ou uma omissão, mas simplesmente de designar um patrimônio responsável que deveria suportar os riscos de danos e de fazer com que o hospital assuma a adversidade"(55).

As decisões Gomez e Bianchi, tomadas pelas jurisdições administrativas em 1990 e 1993, respectivamente, vão realmente alterar a jurispru-

acima enunciado, na medida em que nenhuma delas assumiu a responsabilidade sem culpa dos hospitais por causa dos danos causados aos pacientes (cf. Conseil d'Etat, "Réflexion sur le droit de la santé", Rapport public, EDCE, n. 49, p. 250).

- Notaremos também que o legislador teve uma intervenção na definição dos regimes de responsabilidade sem culpa no setor da saúde pública (as intervenções legais são iguais no quadro público e privado dos atos indenizáveis, aplicando-se nos mesmos termos na medicina pública e na medicina liberal):

Responsabilidade, mesmo sem culpa, do estabelecimento de transfusão sangüínea, para com os doadores (art. L. 668-10, C.S.P.; Art. L. 1222-9, N.C.S.P.).

Responsabilidade sem culpa do promotor de uma pesquisa biomédica, no caso de uma pesquisa sem benefício individual para o interessado, a não ser que haja prova de que o dano não seja de sua responsabilidade ou de qualquer outro interventor de uma pesquisa com benefício individual direto (art. L. 209-7 C.S.P. derivado da Lei n. 88-1138 de 20 de dez. de 1988; Art. L. 1121-7 N.C.S.P.).

Responsabilidade sem culpa do Estado pelos danos por uma vacina obrigatória (art. L. 10-1 C.S.P., derivado da Lei $n$. 64.643 de $1^{\circ}$ de julho de 1964 modificada).

Responsabilidade "mesmo sem culpa" dos estabelecimentos de transfusão de sangue, dos estabelecimentos locais sem personalidade jurídica, do estabelecimento francês de sangue, pelos riscos de doadores em operações de coleta (art. L. 1222-9 C.S.P. derivado da lei de $1^{\circ}$ de julho de 1998 relativa ao reforço da vigilância sanitária e ao controle de segurança sanitária dos produtos destinados ao uso do ser humano).

(54) D. Truchet, "Tout dommage oblige la personne publique à laquelle il est imputable à la réparer", in R.D.S.S., 1993.

(55) S. Clavé, "La responsabilité médicale à l'hôpital public. Evolution et perspectives", éd. Séli Arslan, 2002, pp.141-142. 
dência, na medida em que o regime de responsabilidade sem culpa irá dizer respeito, pela primeira vez, às relações entre os hospitais e seus pacientes.

- A jurisprudência Gomez. o risco inerente às novas terapias.

A decisão da Corte administrativa de apelação no caso dos "Consortes Gomez" irá reconhecer a responsabilidade hospitalar não por causa da culpa, mas para indenizar um risco que o paciente correu. Essa decisão introduz a noção do "acaso" terapêutico, compreendendo um risco ligado ao uso de um tratamento novo cujas conseqüências não são todas conhecidas. Nesta questão, o jovem Sérgio Gomez ${ }^{(56)}$, com quinze anos de idade e sofrendo de uma sifose, foi operado num hospital público pelo método chamado Luqué com a finalidade de endireitar sua coluna vertebral; logo após a cirurgia, o adolescente teve traumas neurológicos e como conseqüência uma paralisia dos membros inferiores. A Corte não constatou falha no desempenho do serviço hospitalar. Entretanto, ela considerou que "o uso de um tratamento novo, quando as suas conseqüências não são totalmente conhecidas, é um risco especial para os pacientes submetidos a esse tratamento; que quando um tratamento semelhante não é usado para uma questão vital, as complicações exepcionais e anormalmente graves, que sejam sua conseqüência direta, implicam, mesmo na ausência de culpa, a responsabilidade do serviço público hospitalar". Além do alcance dessa jurisprudência, pode-se indagar: até quando um tratamento deve ser considerado como novo?

- A jurisprudência Bianchi: o risco hospitalar excepcional.

O Conselho de Estado vai enfrentar seu Rubicão com a decisão Bianchi em 9 de abril de 1993(57), aceitando responsabilidade sem culpa. O Senhor Bianchi foi internado no hospital Timone de Marselha para fazer diversos exames, entre eles uma arteriografia das artérias vertebrais. Quando ele despertou, o paciente estava tetraplégico. Depois de várias perícias solicitadas pelos tribunais, a conclusão foi que não houve erro de natureza médica ou ligado à organização e ao funcionamento do serviço de responsabilidade do hospital público. Em vista destes elementos e levando $\mathrm{em}$ conta a jurisprudência anterior do Conselho de Estado, é obvio que o pedido de indenização do Sr. Bianchi deveria ser negado. Além disso, a jurisdição administrativa considerou que "quando um ato médico necessário para diagnóstico ou tratamento do paciente apresenta um risco cuja existência é conhecida e cuja realização é excepcional e sendo que nenhuma razão leva a crer que o paciente será particularmente exposto, a responsabilidade do serviço público hospital é promovida se a execução deste ato é a causa

(56) C.A.A. Lyon, 21 décembre 1990, Consorts Gomez, Rec. Leb., p. 498, J.C.P., 1991, II, 21698, note J. Moreau; Gaz. Pal., 1991, p. 440, note D. Chabanol.

(57) CE. Ass. 9 avr 1993, Bianchi, Rec. Leb., p. 127. 
direta do dano, sem ter relação com o estado inicial do paciente ou com a evolução previsível deste estado, apresentando um caráter de extrema gravidade".

Se a decisão Bianchi consagrou a responsabilidade sem culpa, devemos constatar que ela se diferencia da decisão Gomez no que diz respeito à natureza do risco médico: se em ambos os casos o risco é excepcional, no caso Gomez trata-se de risco desconhecido, enquanto que no caso Bianchi trata-se de risco conhecido. Desta forma, mais um passo foi dado pelo Conselho de Estado, que logo será seguido de um outro com a decisão de 3 de novembro de 1997, no hospital Joseph-Imbert d'Arles contra a senhora Mehraz $^{(58)}$. Neste caso, uma criança de cinco anos foi internada no hospital para ser submetida a uma fimose por razões religiosas. Durante a cirurgia, feita sob anestesia geral, a criança entrou em coma profundo, que durou um ano, seguido de morte e nenhum erro foi apurado. Com essa jurisprudência, o Conselho de Estado acrescentou que não havia diferença quanto às condições de responsabilidade sem culpa se o ato médico danoso foi ou não realizado para fins terapêuticos. Esta abordagem é particularmente interessante uma vez que anteriormente o Conselho de Estado só aceitava a responsabilidade sem culpa em situações que diziam respeito a pacientes doentes. Por mais louvável que seja o objetivo do juiz administrativo (facilitar a indenização das vítimas), uma tal evolução da jurisprudência não poderia, senão, levantar preocupações e questionamentos na doutrina ${ }^{(59)}$. Além do risco de aumento do contencioso da responsabilidade hospitalar, as jurisprudências mencionadas anteriormente se apóiam, em particular, na condição anormal do prejuízo. Essa condição pode levantar alguns questionamentos. De fato, na opinião de alguns comentaristas, podemos nos perguntar se estaremos sempre à vontade para estabelecer uma diferença entre um prejuízo anormal e um prejuízo anormalmente grave. Não haveria aí, como alguns pensam, um risco de arbitrariedade que poderia ser mal interpretado pela vítimas? ${ }^{(60)}$.

A titulo comparativo, é muito interessante constatar que a jurisprudência civil é claramente contra o princípio da responsabilidade sem culpa na área que nos interessa. A Corte de Cassação, com sua decisão de 8 de novembro de 2000 , acertou um ponto de controvérsia que existiu por muitos anos, decidindo que a reparação das conseqüências do acaso terapêutico não entra no campo das obrigações a que o médico está, por cláusulas contratuais, sujeito a responder ao seu paciente, o acaso sendo definido como a realização, independentemente de qualquer culpa do médico, de um risco acidental inerente ao ato médico e que não pode ser controlado. A Corte de Cassação não vai, portanto, no mesmo sentido da jurisprudência

(58) CE. 3 nov. 1997. Hospital Joseph-Imbert d'Arles, Rec. Leb., p. 470, J.C.P., 1998, II, 10016, nota de J. Moreau; AJ.D.A., 1997, p. 959, obs. MM. Girardot e Raynaud.

(59) V. MM. Bom e Temeyre, obs. ao Dalloz, 1994, somm. Comm., p. 65.

(60) Cf. C. Clément, ob. cit. 
Bianchi, que tinha admitido o acaso. Entretanto, é necessário insistir sobre o fato de que a Corte de Cassação tende a apreciar com relativa facilidade a comissão de uma falta médica. O que, aliás, fez alguns observadores conjeturarem se não seriam a falta de precisão ou o mau jeito no atendimento médico que estariam sendo sancionados. Alguns chegaram mesmo a falar de um aborto da culpa. De qualquer forma, essas discrepâncias de jurisprudência entre o juízo judiciário e o administrativo não é satisfatória. Não seria absurdo se perguntar se não se chegará a ver pacientes optarem pelo setor público, na medida em que, se no setor privado a hospitalização deles apresentar o menor problema, eles terão de se defrontar com o regime de responsabilidade por culpa. É claro que, no plano da eqüidade, não é normal que o paciente do setor privado não tenha o direito de obter reparação quando é vítima de um risco médico, enquanto o consumidor do serviço público dispõe de tal direito. Esta situação ilustra bem a necessidade de uniformizar o regime de indenização das vítimas de acidentes médicos e, sem dúvida, a necessidade de pensar também em outros sistemas de reparação. Tal escolha, porém, é evidentemente da competência do legislador.

\section{A LEI DE 4 DE MARÇO DE 2002, SOBRE OS “DIREITOS DOS PACIENTES" OU A VOLTA À CULPA E A EMERGÊNCIA DA VIA EXTRA-JUDICIAL DE INDENIZAÇÃO DA VÍTIMA}

A lei de 4 de março de 2002, sobre os direitos dos pacientes, aparece como um texto maior do direito francês relativo à saúde, tanto no plano qualitativo quanto quantitativo(61). $O$ título IV dessa lei é relativo às reparações das conseqüências dos riscos sanitários (esse título contém disposições essenciais na área da responsabilidade médica, da indenização dos acidentes sanitários e da obrigação de seguro). Mais precisamente, ele facilita o acesso ao seguro para as pessoas que apresentam um risco de saúde agravado, reafirma os princípios de responsabilidade médica, privilegia o acordo amigável dos litígios, indeniza o acaso terapêutico, renova a perícia médica e facilita a indenização contenciosa das vítimas de hepatite $\mathrm{C}$ de origem transfusional.

Fica claro, a partir da exposição de motivos do projeto de lei, que o legislador deveria, de um lado, precisar, unificar e estabelecer as regras no que se refere à responsabilidade médica em caso de acidente médico, e assim, portanto, solucionar o problema dos custos da lentidão dos processos, das incertezas oriundas da evolução permanente das regras jurisprudenciais e sua diversidade conforme a ordem da jurisdição competente, e, por outro lado, definir um novo direito de indenização na hipótese de acaso

(61) A lei de 4 de março de 2002 é relativa aos direitos dos pacientes. Para uma análise de diferentes aspectos deste texto, ver particularmente sob dir. Anne Laude, "La loi du 4 mars 2002 relatives aux droits des malades et à la qualité du système de santé", in Les petites affiches, numéro spécial du 19 juin 2002, n. 122. 
terapêutico. Era urgente intervir no plano legal, sendo o sistema de reparação muito criticado. De fato, as vítimas eram tratadas de forma desigual conforme o lugar onde ocorreu o acidente médico (estabelecimento privado ou hospital) e no que se refere aos profissionais, e o fato de o juiz ter de procurar a culpa para indenizar, trazia um receio de desvio contencioso como nos Estados Unidos.

No título IV o legislador francês se esforçou, portanto, em fixar limites entre o que depende da responsabilidade médica e o que depende da solidariedade nacional. Essa lei parece inovadora em matéria de direito da responsabilidade, no momento em que cria um dispositivo geral de responsabilidade do acaso terapêutico e pela unificação do direito da responsabilidade que ela produz, além das noções de estabelecimento público ou privado, de setor público hospitalar ou de exercício liberal do médico. Poderíamos resumir a questão numa fórmula lapidar: a responsabilidade para a culpa, a solidariedade para 0 acaso ${ }^{(62)}$. A outra vantagem dessa lei consiste em organizar modos alternativos de solução dos contenciosos médicos.

No que se refere a essa segunda parte, levando em conta o objetivo duplo desta lei (os direitos do paciente e a qualidade do sistema de saúde), convém, de um lado, evidenciar como a lei sobre os fundamentos do direito da responsabilidade e da solidariedade entende melhorar a qualidade do sistema de saúde e, de outro lado, buscar as implicações da lei de 4 de março de 2002 sobre a definição da culpa dos profissionais e dos estabelecimentos de saúde.

\section{A - A qualidade do sistema de saúde pela modificação do regime de responsabilidade ${ }^{(63)}$.}

Com base no direito da responsabilidade e na solidariedade nacional, a lei de 4 de março de 2002 assumiu, como objetivo, tender para a qualidade do sistema de saúde por meio do direito do paciente à indenização em caso de acidentes médicos, em sentido amplo, e do direito de toda pessoa com deficiência física à solidariedade nacional(64). Esse texto fixou

(62) Cf. P. Desideri, “La procédure d'indemnisation amiable des dommages médicaux", in Les Petites affiches, 19 juin 2002, n. 122, p. 69.

(63) Sobre este ponto, ver M-I. Malauzat, "Vers amélioration de la qualité du système de santé?", in Les Petites affiches, 19 juin 2002, n. 122, p. 36. N.B.: o essencial das observações do autor do presente artigo resulta, em parte, da análise desse autor.

(64) Trata-se de uma das mais importantes vantagens da lei. O legislador afirma o direito de toda pessoa portadora de deficiência física (qualquer que ela seja) "à solidariedade de toda a coletividade nacional". Esta prerrogativa é objeto de um título adicional antes do primeiro título da lei. Além deste direito, encontramos três princípios confirmados (a ausência de prejuizo por nascimento, o direito à reparação em caso de erro médico ter provocado diretamente esta deficiência e a indenização do prejuízo moral aos pais de uma criança nascida com deficiência por erro caracterizado do médico durante a gravidez). Este dispositivo foi adotado para fazer face à decisão na plenária da Assembléia da Corte de Cassação de 17 de novembro de 2000 conhecida como decisão "Perruche". Esse direito, de toda pessoa com deficiência física à solidariedade nacional, tem como corolário a indenização baseada na solidariedade nacional. 
um novo sistema de indenização dos acidentes médicos, afecções iatrogênicas e infecções hospitalares, sendo que para o legilador francês a finalidade é encontrar um ponto de equilíbrio entre os interesses das vítimas, dos profissionais de saúde e dos estabelecimentos de saúde.

Nesta perspectiva, a lei impõe princípios novos de indenização e organiza um procedimento para a solução amigável desses litígios.

Sobre o primeiro ponto, a saber, a indenização, ela pode intervir, seja pela responsabilidade seja pela solidariedade nacional para os acidentes médicos, as afecções iatrogênicas e as infecções hospitalares conseqüentes a tratamentos realizados até seis meses antes da publicação da lei ${ }^{(65)}$.

Para indenização por via da responsabilidade, o artigo L. 1142-1, oriundo da lei de 4 de março, enuncia os princípios gerais da responsabilidade médica. Além do caso onde a responsabilidade decorre por causa de um produto de saúde (que decorre da lei de 19 de maio de 1998 sobre produtos com defeito), os profissionais e os estabelecimentos de saúde são responsáveis por atos de tratamento apenas em caso de culpa. O interesse desta disposição é que o legislador reafirma o princípio de responsabilidade por culpa. Sobre esse ponto, trabalhos parlamentares evidenciam que o legislador não desejou modificar o estado da jurisprudência; conseqüentemente, pode-se considerar que a culpa será provada ou presumida.

Entretanto, ao mesmo tempo em que reafirma o princípio da responsabilidade por culpa, a lei reserva dois casos de responsabilidade sem culpa, de um lado no que se refere à responsabilidade por causa de um produto de saúde defeituoso(66), e, de outro, no que se refere às infecções hospitalares quando o dano é por culpa exclusiva dos estabelecimentos e dos serviços de saúde com exclusão dos médicos. Em matéria de infecções hospitalares, os estabelecimentos de saúde não podem ser isentos de responsabilidade a não ser que tragam provas de outra causa (ou seja, na opinião da jurisprudência atual, estabelecendo que a infecção não foi contraída durante a hospitalização).

Apenas para precisar, diríamos que as ações em responsabilidade entre os profissionais e os estabelecimentos de saúde prescrevem após dez anos, a partir da constatação do dano.

O "restabelecimento" pelo legislador francês do princípio de responsabilidade por culpa no direito de responsabilidade médica, no sentido genérico do termo (ou seja, hospitalar e liberal), nos remete à obrigação

(65) A nova duração de prescrição é aplicável desde a publicação da lei, desde então ela é favorável à vítima, incluídas as instâncias em curso cf. art. L. 1142-28 do CSP.

(66) Neste aspecto alguns comentários lembraram, com muito propósito, que de fato trata-se de uma simples aplicação da lei de 19 de maio dse 1998 relativa à responsabilidade dos fabricantes e distribuidores de produtos defeituosos. Esse texto resolveu um processo de responsabilidade sem erro em caso de dano causado por defeito de segurança de um produto. 
imposta pela lei aos profissionais liberais de saúde, aos estabelecimentos de saúde, aos serviços de saúde e à toda pessoa jurídica "além do Estado", exercendo atividade preventiva de diagnóstico ou de tratamento, incluindo os produtores, os que exploram e fornecem produtos de saúde no estado de produtos acabados, usados por ocasião destas atividades, de subscrever um seguro destinado a cobrí-los em caso de responsabilidade "civil ou administrativa" - suscetível de ser promovida pelo fato de danos a terceiros e resultante de atentados à pessoa no quadro de atividade preventiva, de diagnóstico ou de tratamentos. Podemos, também, notar que o novo artigo L. 1142-2 do CSP precisa que o seguro dos estabelecimentos, serviços e organismos acima referidos "cobre seus funcionários" agindo "no limite da missão que lhes cabe", mesmo se estes dispõem de "uma independência no exercício da arte médica"(67).

Quanto à indenização, faz intervir a solidariedade nacional, e esta diz respeito às complicações que não são oriundas de falta, que decorrem de atos preventivos, de diagnóstico ou de tratamentos que tiveram conseqüências anormais para o paciente, em vista tanto de seu estado de saúde como da evolução que era prevista. Entretanto, é importante destacar que o prejuízo deve apresentar para o paciente um certo teto de gravidade, fixado por decreto $^{(68)}$. O dano será apreciado levando em conta a perda de capacidades funcionais e suas implicações para a vida privada e profissional [medida levando em conta a porcentagem de Incapacidade Parcial Permanente IPP — ou a duração da Interrupção Provisória do Trabalho (IPT). No que se refere à Incapacidade Permanente Parcial (IPP), esse teto será fixado por decreto e não poderá ser superior a $25 \%$ ].

A lei previu a criação do Órgão Nacional de Indenização (ONI)(69), dos acidentes médicos, das afecções iatrogênicas e das infecções hospitalares que providenciará a indenização (de modo geral, o financiamento é garantido por meio de uma dotação global prevista na lei de financiamento da seguridade social). O legislador desejou, de fato, pôr um fim às injustiças causadas às vítimas no que se refere à reparação dos danos causados pelo acaso terapêutico. Desta forma, tentou-se substituir um procedimento judiciário longo e custoso por uma indenização(70) "mais rápida e sem proce-

(67) Para uma análise crítica desta obrigação v. F-J. Pansier, "L'obligation d'assurance des professionnels et des établissements", in Les Petites affiches, 19 juin 2002, n. 122, pp. 93-96.

(68) Quando a pessoa, vítima "de um acidente médico, de uma afecção iatrogênica ou de uma infecção hospitalar", sofre um dano cuja gravidade é inferior ao limite fixado por decreto, o segurador do médico ou do estabelecimento é seu único interlocutor. Se um acordo for encontrado sobre o princípio da responsabilidade e o valor da reparação, uma transação amigável poderá ser feita. Se não houver acordo, a vítima deverá endereçar-se ao juízo competente, como tem sido feito até o presente.

(69) A ONI tem o estatuto jurídico de um estabelecimento público administrativo do Estado e está sob a tutela do ministro da saúde. A ONI é financiada por uma dotação da Seguridade Social e pelo reembolso das despesas de perícias, das penalidades e dos recursos sub-rogatórios.

(70) Réforme du droit de la responsabilité et indemnisation de l'aléa thérapeutique, Dictionnaire permanent bioéthique et biotechnologies, Bulletin 113, avril 2002, p. 2282. 
dimento judiciário": no caso em que um acaso terapêutico é constatado, uma oferta de indenização é concedida pelo Órgão Nacional de Indenização(71).

No que diz respeito ao procedimento para a solução amigável de litígios ${ }^{(72)}$, - legislador previu a criação de comissões regionais de conciliação e de indenização(73). Assim, quando o dano sofrido é maior que o limite fixado pelo decreto, a lei de 4 de março de 2002 coloca à disposição da vítima este meio extrajurisdicional de reparação dos danos sofridos. Em cada região, de acordo com os termos do artigo L 1142-5 do CSP "uma comissão regional de conciliação e de indenização é encarregada de facilitar a solução amigável dos litígios relativos aos acidentes médicos, às afeções iatrogências e às infecções hospitalares". É importante destacar que a vítima tem a possibilidade de interpelar a jurisdição competente, ou seja, o processo perante essas comissões é facultativo. No caso de a vítima desejar endereçar-se ao juíz competente, esse último pode, achando que os danos sofridos não envolvem a responsabilidade de um profissional ou de um estabelecimento de saúde, chamar o órgão, que se torna o defensor no processo (art. L. 1142-21). Em todos os casos, a vítima "informa respectivamente à comissão os procedimentos jurisdicionais em curso e ao juiz em causa da provocação da comissão regional" (art. L. 1142-7). Para voltar à comissão, se o dano apresenta as características de gravidade requeridas, ela emite um parecer sobre as causas, a natureza e a extensão dos danos, bem como o regime de indenização aplicável ${ }^{(74)}$. Uma vez emitido, o parecer

(71) N. Reboul- Maupin, "L'indemnisation de l'aléa thérapeutique", in Les Petites affiches, 19 juin 2002, n. 122, p. 79.

(72) Para mais precisão quanto ao processo de acordo amigável v. P. Desideri, "La procédure d'indemnisation amiable des dommages médicaux", ob. cit.

(73) Esta comissão regional é presidida por um juíz da ordem administrativa ou judiciária e compreende representantes das pessoas doentes e dos consumidores, dos profissionais e dos estabelecimentos de saúde, da ONI e das empresas seguradoras. Sua composição, suas normas de funcionamento bem como o procedimento adotado perante a comissão serão determinados por decreto. Ela funciona como órgão de conciliação ou de regulamentação: - quando funciona como órgão de conciliação, ela pode ser contestada por qualquer um que tenha a ver com o respeito aos direitos dos doentes e dos consumidores, com a possibilidade de delegar suas competências a mediadores independentes;

- Ela funciona como órgão regulamentador quando o dano resulta de um acidente sanitário e apresenta um caráter de gravidade fixado por decreto. A comissão emite, então, um comunicado, num prazo de seis meses a contar de seu conhecimento legal das circunstâncias, das causas, da natureza, da extensão dos danos, bem como do regime de indenização aplicável. Trata-se de um procedimento facultativo, a vítima poderá sempre interpelar a jurisdição competente. O conhecimento legal da comissão interrompe os prazos de prescrição. Antes de emitir um comunicado, a comissão regional diligente solicita obrigatoriamente uma perícia médica. Sobre a questão e a pericia v. Th. Coste, "L'expertise auprès de la commission régionale d'indemnisation", in Actualité JuriSanté, n. 34, déc.2001/janv. 2002, pp. 53 et s.

(74) Sobre a indenização das vítimas:

É o parecer da comissão, como órgão regulador, que determina o regime de indenização aplicável. Três hipóteses devem ser destacadas.

1. quando ela considera que o acidente médico envolve a responsabilidade de um profissional ou de um estabelecimento de saúde, o segurador do responsável deve fazer à vítima uma proposta de indenização (nos 4 meses após o recebimento do aviso). A proposta deve abranger a reparação 
permitirá a indenização seja por intermédio da solidariedade nacional, seja por intermédio do segurador.

\section{B - As implicações da lei de 4 de março de 2002 sobre a definição da culpa dos profissionais e dos estabelecimentos de saúde.}

As implicações da lei sobre os direitos dos doentes e a qualidade do sistema de saúde permitem melhor apreender os contornos da culpa dos profissionais e dos estabelecimentos de saúde. $O$ reconhecimento de direitos em favor do paciente permite, em contraponto, melhor definir as obrigações que pesam sobre os profissionais e os estabelecimentos de saúde, cuja inobservância constituirá a culpa ou faltas suscetíveis de engajar a responsabilide, abrindo desta forma em favor do paciente um direito à reparação.

Três dos direitos fundamentais reconhecidos aos pacientes irão servir de linha mestra para balizar a definição da culpa, colocando ao mesmo tempo em evidência alguns dos limites desta lei. Os direitos levados em conta neste estudo são os seguintes: o direito de receber o tratamento mais adequado, o direito do paciente à informação e o direito à maior segurança sanitária possível.

\section{Direito do paciente de receber o tratamento mais adequado} $e$ as obrigações dos médicos e dos estabelecimentos de saúde

Enquanto o art. 1110-1 do CSP reconhece o direito fundamental da proteção à saúde, o art. 1110-5 parece explicitar o alcance deste direito. Este artigo afirma que "toda pessoa tem, levando em conta seu estado de

integral dos prejuizos, após o desconto dos valores dos órgãos socias que são reembolsados diretamente (proposta de caráter provisório quando o estado da vítima não é consolidado, sendo que a proposta definitiva será feita nos dois meses de consolidação). $O$ pagamento é feito no mês seguinte ao recebimento do acordo da vítima. Se a proposta é claramente insuficiente, o juíz acionado pela vítima pode condenar o segurador a pagar à ONI um valor no mínimo igual a $15 \%$ da indenização de direito, além dos danos e interesses devidos por esta razão à vitima.

O segurador dispõe de uma ação sub-rogatória contra o outro responsável, ou contra a ONI se ele julgar tratar-se de acidente sem culpa. Em caso de falta de resposta, de recusa do segurador de fazer uma oferta, de ausência de seguro ou de cobertura de seguro insuficiente, a ONI substitui o segurador. Neste caso, a ONI é sub-rogada contra o responsável ou seu segurador. $O$ juiz provocado pela ONI pode condenar o segurador ou o responsável a pagar à ONI um valor no mínimo igual a $15 \%$ de indenização que ele pretende;

2. quando a comissão regional considera que se trata de um acidente de tratamento sem culpa, a vítima será indenizada a título de solidariedade nacional pela ONI. Se a ONI considerar ter pago indevidamente, poderá entrar com uma ação contra a pessoa que julgar responsável;

3. quando a comissão avalia que o acidente médico é apenas parte da conseqüência de um erro, ela determina a parte da responsabilidade do profissional ou do estabelecimento bem como a que for relevante à indenização da ONI (ex.: em caso de falta de informação). 
saúde e a urgência apresentada, o direito de receber o tratamento mais adequado e de beneficiar-se da terapêutica cuja eficácia é reconhecida e que garanta a melhor segurança sanitária em face do conhecimento comprovado". As fórmulas empregadas nesse dispositivo nos levam a fazer algumas observações, em razão de sua importância para a definição dos direitos dos pacientes (beneficiários-credores da segurança sanitária) e, por reflexo, para a identificação das obrigações dos devedores da segurança sanitária, que são os profissionais e os estabelecimentos de saúde.

Primeiro, reconhecer um direito de receber "o tratamento mais adequado" nos remete à problemática delicada de fundamentar bem as escoIhas terapêuticas, levando em conta as considerações de ordem médicoeconômicas (por exemplo, uma escolha que poderá ser menos eficaz poderá ser mais justificada por uma melhor relação custo-benefício?)

A expressão de "conhecimentos médicos comprovados" é, também, interessante na medida em que ela é nova. O código de deontologia médica e a jurisprudência civil usam até hoje a fórmula "dados adquiridos da ciência". O acesso às terapias só diz respeito, portanto, às conhecidas. Conforme alguns autores destacaram, e com justiça, "esta disposição não tem o único objetivo de proteger a segurança dos pacientes, ela aborda de forma negativa a questão do direito de acesso a um tratamento experimental, da mesma forma em que isso já ocorreu na jurisdição constitucional italiana"(75).

O que pensar dessa inovação legislativa? Por mais sedutora que pareça, ao ver de alguns observadores, não parece que ela seja muito feliz ${ }^{(76)}$. De fato, o termo "comprovado" significa "reconhecido", "verdadeiro", "certo" e "seguro". Ora, a área médica estando dominada pela incerteza científica, parece surpreendente neste caso referir-se à noção de verdade ${ }^{(77)}$. Onde achar a fonte destes conhecimentos comprovados? Esta questão parece delicada num período em que os médicos elaboram uma nova reflexão sobre seu saber ${ }^{(78)}$, quando eles se questionam sobre o modo de elaboração das referências médicas ${ }^{(79)}$. Os conhecimentos comprovados devem ser procurados na literatura científica e médica, nacionais e internacionais, em refe-

(75) V. B Mathieu, "La protection du droit à la santé par le juge constitutionnel", in Les Cahiers du Conseil Constitutionnel, 1999, n. 6, p. 59 et s. e v. no mesmo sentido B. Mathieu, "Les droits des personnes", in Les Petites affiches, 19 juin 2002, n.122, pp.10 e 11.

(76) V. no mesmo sentido B. Guimbaud, "La réparation à la charge des établissements et des professionnels de santé dans le projet de loi relatif aux droits des malades et à la qualité du système de santé", in Actualité JuriSanté n. 34 décembre 2001/ Janvier 2002, pp. 65 et s.

(77) V. D. Jacotot "Le renforcement de la sécurité sanitaire", in Les Petites affiches, 19 juin 2002, n.122, pp. 37-42, p. 39. V igualmente $D$. Thouvenin, "Relativité des données de la science et responsabilité médicale", in Clés pour le siècle, Université Paris II, Dalloz, p .1606 (Echecs de la science) e p. 1612 (consécration de l'incertain).

(78) V. J-P. Boissel "L'information thérapeutique", Masson.

(79) Por exemplo, com a elaboração de padrões, opções e recomendações pela Federação nacional dos centros de luta contra o câncer, in Médecin et Droit, 2000, n. 45, pp. 13-20. 
rências médicas ${ }^{(80)}$ ? Quando várias opiniões científicas se opõem, qual deve prevalecer? Tomando por nossas as observações feitas por um autor, somos levados a nos questionar de forma geral sobre o fato de saber "se é oportuno deixar crer que as escolhas médicas baseiam-se em verdades? Ou é preciso admitir que várias 'verdades', eventualmente contraditórias, possam co-existir. Na prática, várias escolhas terapêuticas são às vezes possíveis, sem que possamos saber, por falta de provas científicas, qual é a melhor quanto à eficácia"(81). Este exemplo mostra bem que a lei de 4 de março deixa várias questões sem resposta.

A formulação do artigo L. $1110-5$ desencadeia várias perguntas ${ }^{(82)}$. Haveria culpa quando o tratamento não é adequado ou quando é adequado, mas não o mais adequado? Um médico é juridicamente culpado quando recorre a um tratamento experimental que, por definição, não tem eficácia comprovada e reconhecida? Responder a esta pergunta, no entender da redação legal muito radical usada no artigo L. 1110-5, é evidentemente pouco confortável. Entretanto, o legislador, afirmando neste mesmo artigo que "os atos de prevenção, de tratamentos, não devem (....) deixá-lo correr riscos desproporcionais ao benefício previsto", dá preciosas indicações. Podemos, razoavelmente, pensar que o médico, em vista dos estado de saúde do paciente, da eficácia dos outros tratamentos, bem como dos perigos do novo tratamento, deve poder recorrer a um tratamento cuja eficácia ainda não foi comprovada, desde que tenha obtido, evidentemente, a concordância do seu paciente.

Enfim, ainda a propósito do artigo L. 1110-5, devemos lembrar que ele dá valor legislativo ao princípio da razão proporcional inscrita no artigo 40 do código de deontologia médica.

2. Direito do paciente à informação e as obrigações dos profissionais e dos estabelecimentos de saúde

O campo e a natureza das obrigações em matéria de direitos do paciente à informação, cujo desconhecimento implica responsabilidade do pessoal e dos estabelecimentos de saúde, foram igualmente modificados pelo legislador. $O$ artigo $L$. 1111-2 reconhece o direito de toda pessoa ser informada sobre seu estado de saúde. A informação compreende as diversas investigações, tratamentos ou ações de prevenção propostas, "sua utilidade, sua eventual urgência, suas conseqüências, os riscos freqüentes ou a gravidade normalmente previsíveis que eles comportam"(83). Uma vez mais,

(80) Cf. D. Jacotot, ob. cit.; v. A. Laude, "La force juridique des références médicales opposables", in Médecine et Droit, 1998, n. 28, pp. 1-3; Ch. Atias, "Les références médicales opposables. Révélation ou continuité?", in R.D. Sant. Soc., 1995, p. 21.

(81) B. Guimbaud, ob. cit.

(82) Cf. a análise de D. Jacotot, ob. cit., p. 40.

(83) Conseqüentemente, aqui o legislador não assumiu a jurisprudência da Corte de Cassação segundo a qual o médico tem a obrigação de informar seu paciente quanto "aos riscos graves que 
as fórmulas legais empregadas são fonte de questionamento. Por exemplo, o que devemos entender por riscos "normalmente previsíveis" ou, mais precisamente, qual é a freqüência que deveremos observar para definir que estamos diante de "riscos normalmente previsíveis"? Pergunta importante, que atualmente permanece sem resposta por causa do caráter recente da lei. De qualquer forma, a interpretação ao contrário do artigo L. 1111-2 permite considerar, em todo caso, que os riscos excepcionais, mesmo graves, não mais deverão ser levados ao conhecimento do paciente ${ }^{(84)}$.

Um outro ponto, referente às exceções à obrigação de informação previstas pela lei, deve ser estabelecido. De fato "apenas a urgência ou a impossibilidade de informar", podem dispensar o médico desta obrigação. Reduzindo as exceções de obrigação de informação a estes dois casos, o legislador não quis assumir a posição da Corte de Cassação, segundo a qual "a limitação terapêutica da informação" pode ser justificada quando "é do conhecimento do médico que a informação quanto aos riscos possa ter uma influência negativa sobre o sucesso das investigações ou dos tratamentos"(85). Finalmente, segundo o artigo L. 1111-4 "O médico deve respeitar a vontade da pessoa após tê-la informado das conseqüências de suas escolhas. Se a vontade da pessoa de recusar ou interromper o tratamento coloca sua vida em perigo, o médico deve tentar de todas as maneiras convencê-la a aceitar os tratamentos que são indispensáveis". Como apreciar os limites da obrigação do médico de convencer a aceitar os tratamentos indispensáveis? Esta é uma pergunta bastante difícil de ser respondida.

\section{Direito do paciente à melhor seguridade sanitária possível e as obrigações dos profissionais e dos estabelecimentos de saúde}

Como interpretar este "direito à melhor segurança sanitária possível", concebido legalmente como sendo um objetivo a atingir, na medida em que a lei de 4 de março não dá uma definição desta noção? Embora seja importante, não é possível nesta exposição tratar deste aspecto que constitui um assunto de reflexão(86), todavia, podemos simplesmente insistir sobre o caráter muito ambíguo desta expressão. (De fato, unindo os termos seguridade e saúde, poderíamos ser levados a concluir que a seguridade sanitária é caracterizada por "situações onde o perigo em matéria de saúde de-

dizem respeito às pesquisas e aos tratamentos propostos", o médico não está isento "desta obrigação pela única razão de que estes riscos são excepcionais." V. Cass. 1 re civ., 7 octobre 1998, JCP, 1998, éd G., II, 10179, concl. J Sainte-Rose, note P Sargos. Sobre a mesma questão vista pela jurisdição administrativa, v. CE 5 janv. 2000, Gaz. Pal., 29 juin 2000, p. 22 et s.

(84) V. neste sentido B. Guimbaud, ob. cit.

(85) V. sobre essa questão o Relatório de 1998 da Corte de Cassação.

(86) V. sobre essa questão D. Jacotot, "Le renforcement de la sécurité sanitaire", ob. cit. 
sapareceu". Estaríamos diante da exigência de seguridade absoluta: não havendo perigo, não há dano. Uma tal compreensão deve, evidentemente, ser rejeitada).

De qualquer forma, o legislador teve a cautela, numa preocupação realista, de afirmar uma exigência de seguridade otimista e não absoluta ("a melhor... possível"). Desta forma, a expressão adotada pelo legislador deixa entrever que existe sempre uma parcela irredutível de acaso, não se podendo, portanto, afirmar uma ausência de risco. Vimos que a reparação dos danos que resultam do acaso terapêutico, com muita lógica, não pesa sobre os profissionais e os estabelecimentos de saúde, uma vez que são inerentes ao tratamento. Entretanto, se fosse comprovado que o profissional ou o estabelecimento de saúde cometeu uma falta, não tendo cumprido a obrigação de informar o paciente, parece possível imaginar que possa deixar nos ombros dos profissionais ou nos estabelecimentos o peso da reparação do prejuizo que resultou do acaso. Esta questão da falha ou não da informação se reveste, conseqüentemente, de grande importância em caso de contencioso, o que dá à opinião do perito um peso considerável. A esse propósito, é preciso lembrar, "que em caso de litígio, cabe ao profissional ou ao estabelecimento trazer a prova de que a informação foi dada ao interessado nas condições previstas pelo artigo L. 1111-2". De acordo com a lei de 4 de março de 2002, a prova pode ser feita por todos os modos.

C - Os limites da lei em matéria de responsabilidade e de reparação

- A questão dos "pequenos riscos".

Em primeiro lugar devemos lamentar que a lei sobre os direitos do paciente não tenha levado em conta o problema dos "pequenos riscos", retomando a expressão usada quando dos debates parlamentares, ou seja, os acidentes que não apresentam um caráter de gravidade suficiente. Alguns parlamentares, entre os quais Claude Evin, propuseram que estes pequenos riscos se submetessem ao "procedimento judicial" (interpretar a expressão no sentido de "procedimentos de direito comum"), a saber, à responsabilidade direta dos agentes de saúde. Como se pôde, às vezes, afirmar com muita justiça "esta expressão não deve fazer crer numa transferência de todo o contencioso da responsabilidade médica aos tribunais judiciários: bem ao contrário, o legislador escolheu conservar a tradicional divisão das competências entre as ordens jurisdicionais 'competentes' de acordo com a natureza e as modalidades de prestação do ato de tratamento na época do dano"(87).

(87) V. sobre este aspecto a análise de S. Clave, ob. cit., p. 271. 
- A ausência de unificação dos contenciosos administrativo e judiciário.

Em 1999, o relatório IGAS/IGSJ "a respeito da responsabilidade e da indenização de acaso terapêutico"(88) preconizava unificar os contenciosos administrativos e judiciários e propunha que optássemos pela competência judiciária, em nome da especificidade do direito médico. Em 2002, o legislador não seguiu essa linha e, conseqüentemente, decisões divergentes entre as duas ordens judiciais devem ser esperadas. As condições de indenização das vítimas estarão sujeitas a ser diferentes segundo o juízo competente, quando o dano sofrido for menor que o limite fixado por decreto. Em contrapartida, quando o dano sofrido for maior que o limite, essas diferenças serão anuladas. De fato, em princípio, o consumidor do serviço público e o cliente dos estabelecimentos privados serão indenizados. De acordo com Benoît Guimbaud, "neste caso, as eventuais divergências de jurisprudência serão apenas de interesse dos seguradores". Entretanto "podemos imaginar que uma atividade médica se torne insegurável", como, por exemplo, as ecografias fetais, "quando essa atividade for exercida no setor liberal, mas permanecendo assegurada no setor público"(89).

\section{CONCLUSÃO}

O panorama da evolução do direito da responsabilidade, antes da intervenção da lei sobre "os direitos dos pacientes e a qualidade do sistema de saúde", evidencia que o juiz, e mais particularmente o juiz administrativo, tomou certas liberdades com a filosofia da responsabilidade. A jurisprudência manteve e reforçou sua obra indenizadora por meio de uma interpretação muito liberal das condições do compromisso da responsabilidade e do direito à reparação, principalmente com o recurso à técnica da inversão do ônus da prova, naquilo que concerne à culpa, ao vínculo de causalidade. Igualmente, o desenvolvimento da responsabilidade sem culpa veio turvar ainda mais a situação. Assim, era importante romper a desigualdade de tratamento dos "pacientes-vítimas", de acordo com a situação da ocorrência do acidente médico.

Evidentemente, é ainda muito cedo para fazer um julgamento sobre as conclusões e inovações introduzidas no Código de Saúde Pública pela lei de 4 de março de 2002. A priori, parece que os resultados tenham sido alcançados no plano teórico, a saber, garantir a estabilidade do contencioso médico unificado em torno de uma regra de direito comum à ordem administrativa e à ordem judiciária. Esta unificação permitirá, sem dúvida, fazer realmente uma "obra de justiça". Devemos, portanto, considerar que

(88) Rapport sur la responsabilité et l'indemnisation de l'aléa thérapeutique, septembre 1999, p. 71.

(89) B. Guimbaud, ob. cit., p. 63. 
esta lei constitui um progresso maior. As melhorias introduzidas pela lei são várias, como por exemplo, o fato que, de agora em diante, os profissionais de saúde e as instituições não mais correm o risco de ser condenados na ausência de culpa, assim "exit" a jurisprudência Bianchi; o fato que a ONI garanta a indenização da vítima desde que determinadas condições sejam preenchidas; ou a obrigatoriedade do seguro para garantir a responsabilidade civil ou administrativa sujeita de ser promovida em razão de danos sofridos por terceiros e resultantes de atentados à pessoa no quadro de atividades de prevenção, de diagnóstico ou de tratamentos. É claro que estas melhorias não anulam a complexidade ligada à manutenção de uma dupla competência jurisdicional, fato que se mostra particularmente incômodo no quadro da cooperação onde intervêm agentes do setor público e privado: em caso de contencioso, as duas ordens de jurisdição deverão ser provocadas se houver cooperação que envolva a instituição pública, os profissionais liberais e os organismos privados ${ }^{(90)}$. Em conseqüência, divergências de jurisprudência, como por exemplo, sobre a interpretação da noção de culpa, sobre a presunção ligada à infecção hospitalar, podem muito bem ocorrer ${ }^{(91)}$. Vários estudos colocaram em evidência as diferenças práticas entre o juízo administrativo e o juízo judiciário. Assim, o juiz administrativo totaliza o montante das indenizações, à diferença do juiz civil, as avaliações não são feitas da mesma forma, como pôde mostrar a contaminação por vírus do HIV logo após uma transfusão de sangue ${ }^{(92)}$. Podese portanto lamentar, ao mesmo tempo em que se parabeniza as melhoras consideráveis da lei de 4 de março de 2002, que o legislador não tenha completado o regime de unificação, atribuindo o conjunto dos contenciosos oriundos da atividade médica a uma só ordem de jurisdição, por exemplo, a ordem judiciária. Mas o Direito não é uma "coisa" congelada, pode-se razoavelmente esperar que o legislador, na sua grande sabedoria, saiba ultrapassar esse novo patamar... Isso, porém, é uma outra história.

(90) Cf. a análise de C. Esper, "La loi du 4 mars 2002: le renouveau encore imparfait de la coopération entre acteurs de santé", in Les Petites affiches, 19 juin 2002, n.122, p. 66.

(91) Art. L. 1142-1-I do C.S.P.

(92) Sobre este aspecto v. G. Viney, resp. civ., J.C.P. 1997, I 4070, n. 36; citado por C. Esper, in ob. cit. 